\title{
Teaching in a Liberal Arts College: How Foreign Language Courses Contribute to "Writing Across the Curriculum" Programs
}

Ilona Klein

Brigham Young University - Provo, ilona_klein@byu.edu

Follow this and additional works at: https://scholarsarchive.byu.edu/facpub

Part of the English Language and Literature Commons, and the Reading and Language Commons

\section{Original Publication Citation}

"Teaching in a Liberal Arts College: How Foreign Language Courses Contribute to 'Writing Across the Curriculum' Programs," MLJ, The Modern Language Journal, 74 (Spring 1990), 28-35.

\section{BYU ScholarsArchive Citation}

Klein, Ilona, "Teaching in a Liberal Arts College: How Foreign Language Courses Contribute to "Writing Across the Curriculum" Programs" (1990). Faculty Publications. 3827.

https://scholarsarchive.byu.edu/facpub/3827

This Peer-Reviewed Article is brought to you for free and open access by BYU ScholarsArchive. It has been accepted for inclusion in Faculty Publications by an authorized administrator of BYU ScholarsArchive. For more information, please contact ellen_amatangelo@byu.edu. 


\title{
Teaching in a Liberal Arts' Ciollege: How Foreign Language Courses Contribute to "Writing Across the Curriculum" Programs
}

\author{
ILONA KLEIN \\ Loyola College in Maryland, Baltimore
}

THIS ESSAY SHARES SOME THOUGHTS ABOUT the need for interaction between foreign language instructors and English teachers, both in high schools and at the university level. ${ }^{1}$ As a foreign language teacher for the past nine years (the last four in a liberal arts college), I have encountered several problems and difficulties that could be overcome, I believe, if English, Writing, and Foreign Language departments addressed them together. I do not claim to be able to give definite answers, since many pedagogical concepts concerning L2 acquisition/ learning and their possible application to writing programs remain misunderstood or are presently debated by teachers and scholars alike. I merely wish to offer the results of three interesting years of informal talks with colleagues in other disciplines, all of whom are interested in trying to find a better means of promoting effective writing.

During the past decade, an increasing number of liberal arts colleges have adopted programs which were first experimentally created. Within the framework of a liberal arts education, the general curricula studiorum have been conceived with the intention of "delivering" at graduation a well-rounded citizen and individual, capable of reading and writing with productive competency. Personal individual growth and comprehensive education are im. portant goals in this tradition, which pursues the enhancement of critical and constructive thought. A fully developed liberal arts core program offers a solid background in basic con-

The Modern Language Joumal, 74, i (1990)

0026-7902/90/0001/028 \$1.50/0

-1990 The Modem Language Joumal cepts of the humanities and sciences, thus enhancing the understanding of both disciplinespecific concepts and their implications for wider social and political issues. Among several innovations, "Writing Across the Curriculum" (WACU), or "Writing in All the Disciplines" has become the best known and most widely accepted. Its underlying concept is to teach students to write effectively in all subjects of their studies; it purports an alleviation or elimination of the traditional barrier between humanistic and scientific disciplines. In this context, "writing" must be understood also as a tool to enhance thinking, rhetoric, and "method": i.e., teaching writing as a teaching/ learning tool. Since all students must learn to write term papers coherently and cohesively, it follows that to achieve this they must learn to use the lexicon and rhetorical modes which are meaningful and appropriate to the discipline for which they are writing.

Traditionally, most English majors are capable of writing exemplary essays and term papers, employing acceptable and correct style for a specific context. However, it must be acknowledged that too many majors in scientific or non-literary disciplines are often unfamiliar with textual development in their areas. One of the goals of the WACU program is to reduce the disparity of the quality of writing in English/Writing departments os. other areas. The first of numerous problems facing those who introduced WACU to their academic communities was the challenge to involve the widest number of faculty members, representing as many disciplines as possible, in the project. As an example of the difficulties encountered, I give a firsthand experience: When approached about the possibility of taking part in the 
WACU program at Loyola College (Baltimore), a young faculty member from Engineering quickly rejected the idea, for he had already been disappointed to see how "well" some of his students had been trained in the "skill" of writing. Though some of them were not capable of solving specific engineering problems, they could produce midterm papers which looked "just great." This colleague was unimpressed, to state it mildly, by our efforts to teach students how to write effectively, for he saw in the writing program only a lesson on how to deliver a "nicely written" paper, with little or no regard to its substance. ${ }^{2}$ This example typifies the skepticism and misconception held by many regarding WACU.

Instructors' participation in the program is entirely voluntary, and even though most colleagues who teach foreign languages support the idea and apply its general principles, only a few have taken active part in campus workshops and seminars on this topic. Teaching foreign languages at Loyola has made me aware of the need to define clearly our expectations for the program in the different subjects taught.

Before talking specifically about writing in foreign languages, I need to explain the scholastic background of our students, and the linguistic requirements expected of them. At Loyola, the four-semester language requirement expected of all students in all disciplines (1987) has received various reactions. ${ }^{3}$ Students enroll in language courses which are open to all, without differentiation between majors, i.e., honors students do not have the option of a "preferred" or "accelerated" language section, and majors in subjects not obviously connected to foreign languages do not have "slower" language classes. This non-diversification of language courses often dismays some business and/or math majors, and those who are more interested in non-humanistic topics. These students have become quite vociferous lately, protesting against the four-semester requirement, for they feel that such extensive foreign language training bears little or no significance to their general education. Moreover, the point of contention lies in the fact that some years ago, following the trend of other curricula across the country, Loyola instituted classes known as "science courses for non-science majors" (students refer to them as "Kiddy Chem," "Baby Bio," etc.). These courses emphasize a humanistic or anthropological approach to the subjects treated: drugs, nutrition, and ecology may be some of the topics considered in these science lectüres for non-science majors. The classes, while shifting the focus of the topic, do not lack rigor, and, it is felt, are required for a wellrounded education. They are science courses which fulfill core requirements for students not majoring in scientific subjects. A liberal arts education, proponents asserted, did not need to impose a profound study of specialized scientific topics for students who desired to concentrate their efforts on humanistic subjects. In 1987, when the language requirement was increased from two semesters to four, many students majoring in scientific disciplines expected a "Baby Language" section, similar to the "Baby Science" courses now offered for non-science majors (while, for instance, "Business French" is a legitimate, specialized upper-level course which requires mastering specific lexicon and syntax, one semester of a "Baby Foreign Languagen for Business majors would not be acceptable).

If this sounds disappointing, it is, especially for those of us who feel we must offer a wellrounded education to the decision makers of tomorrow. Something seems to be going seriously awry. Many educators, concerned about the attitude of those students who try to avoid learning and still graduate, are disillusioned by reactions similar to those of my Engineering colleague. Others who complain about students handing in well-written papers ("and laser printed, most of the time!') demonstrate simultaneously little understanding and caring for the need to educate technicians who are linguistically capable of contributing significantly to discourse in the world of science. One needs to understand these colleagues who believe that colleges should invest less effort in developing writing skills, and instead give science instructors more time to teach fundamental math, trigonometry, and the like. Although other teachers can sympathize with this frustration, nevertheless the concern exists for instructors who are not in the Humanities, and who react negatively to writing programs. As pointed out above, WACU pertains to all disciplines, and enhances thinking skills through writing, and as such it ought to be incorporated into general core programs by the widest number of departments of liberal arts colleges in this country.

I have so far mentioned the WACU program in general, and, more specifically, its status in English and in English-taught courses. Before 
beginning a discussion pertinent to FL teachers, a few points still demand attention. Normally, our students begin foreign language study in the freshman year (there are, of course, those who choose to wait until junior status). Loyola College, as do other institutions, offers a placement test to all incoming freshmen, so that students who already have had foreign language courses in high school can continue to build their linguistic capabilities, instead of having to start over from ground zero. Our very general assumption is that each year of foreign language study successfully completed in high school corresponds to roughly one semester of college work in that same language. ${ }^{4}$

As in other higher education institutions around the country, at Loyola not all incoming freshmen have prior training in a foreign language. However, among those who have, the general trend seems to be to continue the instruction in that same language, if the student has achieved good results in high school. On the other hand, the students who have experienced difficulty with a foreign language in high school more often will opt for a second, different language, starting at beginners' level: those of the former group are tabulae rasat in terms of second language acquisition; the latter group, instead, is composed of young men and women who start the new language with a baggage of linguistic frustration behind them. Moreover, almost always members of these two groups converge in the same classroom environment, with the result that some students are eager to learn what a foreign language may teach them, while others try to deal with old fears and their preconceptions of previous failures.

Having tried to portray who our students are, I focus now on the challenge of teaching a specific target language to these students and incorporating these principles into writing programs. Learning grammar is one component of most foreign language programs. And teaching grammar appears to represent one of the most demanding tasks which my colleagues and I face each semester. We do not adhere to the principles of traditional language instruction: the majority of us teach speaking as much as possible in the target language, using a communicative approach, all the while restricted by the fact that beginning language courses meet between 150 and 250 minutes per week, depending on institutions. Even with the use of conversation, the need for defining precise grammatical terminology and concepts still exists. These cannot and should not be avoided; hence words such as "noun" or "reflexive verb" are used quite frequently in class, and by encouraging the use of correct grammatical nomenclature (transitive verb, possessive pronoun, passive form of a verb, and so on) we underscore the importance of such concepts to the language learning process. The majority of students in advanced language courses are familiar with these terms, and have come to understand the paradigms of the language they are exploring. What matters is the students' understanding of these concepts, and their familiarity with appropriate nomenclature. When teaching L2 with 150-250 contact minutes a week, the classroom situation cannot reproduce accurately a natural first language acquisition experience, hence other cognitive strategies must be employed. Acquisition-oriented goals and methods are desirable, though learning grammar and conscious analysis must also form an integral part of this process.

Unfortunately, quite often beginning students (both those belonging to the labula rasa category, as well as those who have experienced previous unsuccessful encounters with a foreign language) become uncomfortable when first faced with such terminology. Although most of these young men and women come from high schools which take pride in offering a good background in several disciplines, the majority of our beginning language students claim never to have attended an English grammar class (nor a writing class in high school) in which the meaning of such grammatical terms has clearly been defined for them. Of course, the grammatical concept of an intransitive verb remains the same, whether it applies to Spanish, Italian, English, or French. The idea of case is also inherent to linguistic analysis. However, the problem is that these concepts are not universal in their application, and the definitions are not able to apply to all cases. Moreover, foreign language professors may need to teach grammatical elements which may not be the same ones English/writing professors must clarify. For instance, while the correct position of an in/definite article may be important in foreign language acquisition, L1 teachers will focus on the standard use of the in/definite article. Some of the terms and categories they imply may be language-specific: "II plural" is of less interest 
in English with respect to verb forms than it is in Italian, for example, since in English the II singular and plural forms are identical.

When students are first asked to recognize simple grammatical structures and linguistic patterns (the number of a subject, the characteristics of an adverb, the position of an indefinite article), many feel intimidated. The abovementioned concepts are, of course, notions of which the students are already aware, if not formally, at least at an intuitive level. However, since they lack the knowledge of conventional nomenclature, students appear frustrated and discouraged as soon as the matter is brought to their attention. They are generally concerned about lacking knowledge of standard grammatical terminology; such perceptions appear to be overwhelmingly present, not only in those groups who have not had prior exposure to a foreign language, but also in quite a few of the individuals who claim to have attended one or more semesters of English/writing in high school, or at the college level. Most students familiar with conventional nomenclature have confirmed that knowledge of English grammatical terms and structures frequently comes from a previous exposure to foreign languages, because former language professors made such expressions clear. Several colleagues from English and writing departments have confirmed that their own awareness of grammatical nomenclature comes from exposure to foreign languages. Even though effective teaching and learning L2 (and natural acquisition) take place also without the use of grammatical labels, nonetheless to be familiar with the concepts represented by these labels means to recognize linguistic constituents to which most teaching methodologies will make reference. For L2 instructors who believe in a complete communicative approach, knowledge of conventional nomenclature is useful to point out contrastive patterns, to underline points of interest, to draw students' conscious attention to patterns for which they may have intuitive understanding. Again, the point is not that through deep knowledge of traditional grammar our students will be able to achieve better results in learning to write in a target language; however, awareness of area-specific nomenclature, together with the necessary linguistic understanding of grammatical concepts connected to such terminology, requires that students use judgement while creating compositions. Hence, writ- ing is employed as a means of developing critical capabilities, and clear thought is of primary importance in the writing process.

When I started to investigate this situation, I first solicited information from colleagues who teach foreign languages, and who confirmed that their experiences are very similar to that described above. I then approached some teachers and professors of English (in high schools and colleges/universities) across the country. ${ }^{5}$ The same type of concerns surfaced in each conversation. I realized that throughout the United States we deal with similar educational problems, perhaps with slightly different twists. During these conversations, I expressed concern about the fact that my students were not familiar with basic grammatical nomenclature, even though they seemed to be well aware of the principles of writing in English and had attended one or two semesters of formal training in such courses. Colleagues teaching English/writing explained that rarely would an occurrence appear in which they would need to utilize exact grammatical terminology to explain the use of specific grammatical peculiarities to the students. ${ }^{6}$ One of the teachers with whom I talked, who had been teaching English for four years, pointed out that she had just returned from a summer seminar/workshop, in which she was exposed to what she called a "holistic approach" to her students' writing. This method (which bears different labels) is relatively widespread now in our country: it recommends that teenagers' essays be evaluated more generally, that main consideration be given to the overall sense of coherence and to the development of thought in compositions than to a methodical spotting of each improper grammatical use of the language. Inherently, this entails the danger of losing sight of the trees for the forest. The dangers of exclusively pursuing a "holistic approach" method result in an insufficient understanding of linguistic structures.

An example will illustrate my concerns more clearly, while also giving some practical indications on how to incorporate writing programs' principles into foreign language courses. Around the second week of beginning Italian, I ask for a brief, simple but correct, written dialogue between two invented characters ("my sister" and "I," for instance). When the first draft of the homework is handed back, approximately two-thirds of the students in each class 
have identified the characters of the dialogue with English subject pronouns, instead of Italian proper names. And of this group, about seventy-five percent uses me and him/her, instead of "I" and " $\mathrm{s} / \mathrm{he}$ " as captions. ${ }^{7}$ As I hand back the corrected versions, I merely circle this erroneous English use of the accusative case, and ask what is wrong with the use of these personal object pronouns. During the peer review, those students who already have been exposed to another foreign language (and thus to "pedagogical grammar") are usually capable of perceiving the mistake (these are also, however, the students who do not make such errors). A few among the remaining youngsters can intuitively spot the mistake, but are incapable of explaining it in grammatical terms. Typically, several students do not perceive any mistake in the above-mentioned example. For them (roughly fifty percent of the class) not only is the notion of "accusative" os. "nominative" (or direct object pronouns os. subject pronouns) a completely alien concept, but, more discouragingly, since they lack an adequate background in these general grammatical concepts and common terminology, they are not prepared to perceive these notions.

This is the discomforting reality of which educators must be aware, about which we must talk, and about which we must do something. I do not advocate absolute and constant linguistic purity (for such does not exist); however, it is important, for instance, that teenagers be made aware at least of the error in responding "real good" to the question "How are you?" (by using an adjective as modifier of another adjective). ${ }^{8} \mathrm{I}$ would much rather hear this use of non-standard language made consciously, than ignorantly. By making sure that each tree is well planted, we would probably have a better forest, too.

I do not question the programs. I am confident that programs in English, writing, and foreign languages across the country have been updated in the last years. When taken individually, each of these three areas offers attractive and stimulating courses which fulfill the peculiar, respective needs of a specific field. Instead, my concerns are directed toward an effective integration of our teaching efforts, so as to tender a balanced education in many fields.

The concept of WACU presents special considerations when applied to students learning a foreign language. Naturally, most of the spe- cific difficulties arise because these young men and women are not writing in their native tongue, and hence are faced with the knowledge of only a restricted vocabulary, together with basic linguistic structures. ${ }^{9}$ As students grow linguistically, they will be able to master a wider array of language patterns and functions. To teach students how to write in a foreign language rarely means to evaluate an overall pattern of consistency, and offer suggestions concerning style and rhetoric; more often, it implies merely the written consolidation of acquired verbal skills which include basic and relatively simple linguistic paradigms.

Moreover, special pedagogical provisions must be made when teaching a foreign language to non-English native speakers. Generally, students whose native idiom is non-Romance will encounter certain relatively predictable obstacles when approaching Romance languages, while English native speakers may feel more or less comfortable in approaching peculiar linguistic structures of German, for example. In many urban communities, where foreign heritage is still proudly alive, teenagers may be anglophones and dialectophones simultaneously. In this latter case, our experience shows that when entering a high school or college foreign language program, the student is likely to enroll in the foreign language course of his or her cultural background: in these cases, teaching to write in the target language consists mainly in training the student to differentiate between dialectal expressions and acceptable standard idioms of the language in question.

Thus, when departments of foreign languages join writing programs, one may not expect the core of the program to evolve in a fashion similar to that given by our colleagues in writing or in English departments. For those language instructors who do not exclusively adhere to an inductive method, but employ a combination of inductive/deductive approaches, to use only a "holistic" or "content" approach would be more detrimental than effective, because the students must first learn to master correctly very basic and specific linguistic structures, and only at a second stage, when these patterns have become familiar, they can build and elaborate further upon such elementary schemes. Even though at an elementary or context-bound level a simple paragraph in L2 should be not only grammatically correct, but also congruous in content (thus emphasiz- 
ing the relationship between function and form), at this level for most foreign language educators teaching beginners' writing is equivalent to offering well defined grammatical situations and letting students explore a topic cautiously, employing their very limited linguistic knowledge. ${ }^{10}$ While the English essay of a teenager can be measured against the youth's knowledge or lack of knowledge of contemporary political issues, themes assigned in a beginning foreign language class will most likely deal with "here and now" topics, and be evaluated according to more rigid guidelines of grammatical and orthographic exactness.

Most foreign language departments have established goals for introductory and intermediate language classes, and for each level the list is divided into five categories: speaking, listening, reading, writing, and culture. ${ }^{11}$ Based on the ACTFL Guidelines for writing, Loyola's goals for introductory courses specify that "students will be able to write a short, grammatically correct paragraph on a familiar topic"; for intermediate classes they will "be able to compose short paragraphs or take notes on familiar topics founded in personal experience. They will be able to write a coherent composition based on the thesis-subthesis model. . . . Can discuss likes and dislikes, daily routine, everyday events, and the like"; in composition and conversation courses, the "students will be able to write descriptive, narrative and expository prose. They will also be able to proofread their own and others' work for errors in mechanics, organization and stylistics"; in upper division culture and literature courses, "students will be able to express themselves effectively in test essays, summaries, and critical and interpretative analyses." As stated above, these are our goals for each level of language learning, and we do not expect all of the students in any given class to become so proficient as to fulfill all of our expectations. Generally speaking, we evaluate as $\mathrm{A}$ or $\mathrm{B}+\mathrm{a}$ student who meets the standards suggested by these guidelines, and who can successfully reproduce and/or create given linguistic situations orally and in writing. As is obvious, then, to learn the art of writing in a foreign language will imply to master basic linguistic skills - at the beginning - and slowly proceed toward more elaborate structures, which also will allow a more personal response . to the topic assigned.

When foreign language students are assigned written homework (be this the creation of a simple, straightforward dialogue, during the first weeks of exposure to the target language, , or an essay on a familiar topic, during their thind and/or fourth semester, or a critical analysis of a foreign literary piece, at their advanced stage of learning), it appears most beneficial to create peer editing groups in class: here students can discuss pertinent ideas among them"selves in the target language, and exercise orally those grammatical/linguistic patterns and changes in content which they wish to incorporate into the first written draft of the assignment. The processing of meaning and form simultaneously at elementary levels (enhanced through peer editing) is a cognitive and metacognitive problem, not resolved by merely teaching grammatical nomenclature or emphasizing structures. After handing in the draft, which the teacher marks, clarifies, and returns promptly, often the students meet briefly in small groups once again (these groups need not be necessarily composed of the same students who formed the first groups) and work out with the help of each other and of the instructor passages which seem to be the most difficult. At home, later, each student individually re-writes the original essay or dialogue, including now all necessary corrections and taking into consideration peer suggestions and teacher's comments. Unless some major problems are discovered, the second is usually the final version of the assigned homework, and the one which is graded. Frustration sets in during the process of giving feedback to our students, for we feel the discouraging lack of English grammatical background in the youngsters. It is time-consuming and cause for great disappointment for foreign language instructors to have to teach and/or explain English grammar and nomenclature besides the linguistic peculiarities of the foreign idiom involved. ${ }^{12}$ If our students only knew what an English subjunctive is and how to employ it correctly in L1, we could be much more efficient and effective in teaching the same concept, from a contrastive point of view when necessary, in the target language. Instead, many of us must use precious class time to explain the conceptual difference between a transitioe and an intransitive verb, just to mention one of too many examples.

Concerns are strongest here, hence the need - to share these points with colleagues of other writing programs. The dialogue between English departments, writing departments, and foreign language departments must be more effec- 
tive and stimulating. We are teaching the same principles to our students, i.e., how to use a language correctly and efficiently, yet - for some reason - the communication among our disciplines seems to be closed off. If we want to give students the quality education they deserve, the well-balanced knowledge that liberal arts colleges advertise, and the humanistic instruction that these youths merit, we need to communicate more among ourselves. We do a disservice to our institutions, to our students, and to ourselves if we isolate the foreign language teachers from the English and writing instructors.

This essay has pointed out basic contributions which foreign language teachers can offer to WACU programs. Questions which we must still ponder and discuss are: How can writing/ English departments cooperate more efficiently with language professors and vice versa? Would an English grammar course (perhaps mandatory for freshmen) suffice to clear the concerns about lack of knowledge of nomenclature, and proper use of structures? Or would the creation of such a course soon become obsolete within more modern programs? Could a brief, but intense, series of lessons on grammatical nomenclature and its practical applications be sufficient to prepare our students for the task of learning different linguistic/grammatical

\section{NOTES}

'This essay is based on a paper delivered at the RMMLA, 1988. My gratitude goes to Fr. Brunette, S.J., Richard Auer, Richard Donato, all of Loyola College, and to Thomas Cravens, University of Wisconsin, Madison.

${ }^{2} \mathrm{~A}$ common complaint against WACU programs is that we train our students to produce eloquence with little substance. We need to inform more clearly colleagues in other departments about the goals we wish to obtain, so that a dialogue can be opened and misunderstandings overcome. The fact that students' papers may or may not contain discipline-specific substance to them, regardless of how nicely these papers are written, is hardly a realistic complaint to move against WACU.

sActually, Loyola requires that students reach the equivalent of what our FL/Literatures department defines as "level four," i.e., a linguistic knowledge which equals the completion of four semesters of any L2. In reading, writing, speaking, and understanding, we expect students to perform roughly at an "intermediate/mid-high" level on an ACTFL scale, with a few of the best students mastering perhaps an ACTFL level two.

IIf there were, indeed, such a clear correspondence, then structures in L2? If so, who is better prepared to teach such a course-foreign language or ¿English/writing teachers? At what level should a "nomenclature" class be offered, if it should be offered at all? As a starting point, liberal arts colleges might want to consider a well-designed "Introduction to Language" class which - when properly structured-can fascinate students and present them with a painless introduction to grammar while raising linguistic consciousness. The last question to ask is whether or not it is necessary to wait until the students are of college age to fill their linguistic gaps. Are not these concepts useful and necessary for high school students as well? 13

Until now, most English/writing and foreign language departments have not worked in collaboration (and this is evident when one notices the troublesome low percentage of foreign language professors who participate in national or regional writing conferences and seminars, for instance). However, as educators we can offer a solid liberal arts core by taking time to explain to each other our pedagogical needs and concerns, by exploring what we have to offer, and by making the effort to share with one another new ideas, methods, and strategies for an improved writing program which will truly be across the disciplines.

no placement test would be needed; however, since high school programs, teachers, methods, and students differ, so the results differ, too. The majority of our students perform fairly predictably in these placement tests; nevertheless, at the beginning of each semester we face "misplaced" students, some of whom are individuals who perform poorly under testing conditions, and a few of whom purposefully make mistakes to "under place," thus enabling them to breeze through an easy $A$. Some modifications to the entrance test are auspicable, so that it will reflect as accurately as possible the actual L,2 knowledge of our students, and avoid cases of under placements.

${ }^{5} \mathrm{My}$ investigation had no systematic structure. I merely met informally with English teachers and instructors to discuss these concerns at professional conferences across the country (GA, MD, WY, OH, NM, WI, UT, FL, WA). All colleagues were very eager to cooperate and share ideas in this matter. I remain grateful for their interest, time, and sense of collegiality.

'Research done in the past fifty years, but especially in the sixties, has abundantly proven that teaching L1 or L2 to students colusioely through the explanation of grammatical principles does not improve the overall quality of their writing (sce Scherer \& Wertheimer, and Smith in the bibliography), nor does it guarantee a better understanding of writing techniques. However, my point stresses the im- 
portance of English and writing teachers showing their students acceptable linguistic patterns while referring to these with proper terminology. Understanding the concept which lies behind a term means to exercise critical judgement when recognizing such patterns, and thus enhances our students' thinking process.

To exemplify, I am looking for a brief dialogue such as: io: "Ciao, Teresa, stei bene oggi?' Cosa studi par domani?"; Teresa. Sono stanca, oggi. Dero studiare l'italiano e la filosofia. E tu?"; io: Sto berissimo oggi. Ora oado a mangiare e dopo studio la biologia. Ciso, Tresal'; Terese: "Ciao, Silvia!". Instead, what I am handed often has "io" and "Teresa" (in Italian) replaced by "me" and "her" (in English-while the dialogue is still composed in Italian). The subject pronouns used are non. standard native English ("me," "her"). When students write "Bill and me went to the movies yesterday," this is the pattern they will try to transpose into German, for example (where "Wilhelm und mich sind gestem ins Kino gegangen" is just as unacceptable in a classroom context as its corresponding non-standard native English). My point is that these native idiomatic non-standard uses of L1 should be explained and corrected at an earlier age, and not be left to linger as relatively common expressions until students become college freshmen.

This phenomenon is developmental, hardly remedied by the knowledge of grammatical terminology. This essay is not meant to prove that students who know nomenclature may or may not use correctly an accusative or a nominative pronoun in natural language tasks. It is importane that our students learn proper use of standard English, just as they are taught standard forms of L2, because-whether we agree with it or not-judgements about competence or intelligence are made according to the way people speak or write. Whether these judgements are correct or not is another topic altogether. Our students must be aware that any language has different registers, each of which has appropriate and acceptable uses within specific contexts of situation.

${ }^{9}$ According to Gaudiani, while native speakers actively make use of about eighty-five percent of vocabulary and

\section{BIBLIOGRAPHY}

1. ACTFL Proficiengy Guidelines. Hascings-on-Hudson, NY: American Council on the Teaching of Foreign Languages, 1986.

2. Adorni, Sergio \& Karen Primorac. English Grammar for Students of Italian. Ann Arbor: Olivia \& Hill, 1982.

3. Brown, H. Douglas. Principles of Language Learning and Teaching. Englewood Cliffs, NJ: Prentice-Hall, 1980.

4. Chaudron, Craig. Second Language Classrooms: Research on Teaching and Laoming. Cambridge: Cambridge Univ. Press, 1988.

5. Corbett, Edward P. J. The Lillle English Handbook: Choices and Conventions. 4th ed. Glenvièw, IL: Scott, Foresman, 1984.

6. Danesi, Marcel. Theory and Practice in Language Teaching." Spurti e rictrche 2 (1986): 91-103.' structures in their tongue, people learning to write in L2 often will be able to manipulate effectively less than fifteen percent of words, sentence patterns, and idioms. Although language learning is not achieved solely through patterns and structures, a number of students feel more comfortable when introduced to new grammatical concepts of L2 through visualization of some type of scheme. The issue is not grammaticality os. non-grammaticality, it's "how," "when," and "what" works and "with which" type of text grammar, in English as in foreiga languages. Which problems are English composition students experiencing, and can grammar alone solve at least some of their problems? Are the problems seen in L1 and in L2 "local" or are they truly "global"?

"It could be argued that "coherence" should be a goal in every piece of writing no matter how complex it may be. The point, bowever, is that generally speaking there is not much conoeptually sophisticated writing done during the first and second semesters of L2 instruction.

"At Loyola, these goals are available to all students, upon request, in the form of handouts which circulate freely in our department. Moreover, incoming freshmen who enroll in Writing 113 and/or History 101 (practically ninety-nine percent of all freshmen at Loyola College take these courses) must purchase the Loyola College Wiriting Handbook which spells out writing requirements of each department on carnpus. Freshmen are also required to purchase Corbett's Hardbook of English grammar.

${ }^{12}$ Since grammar is not isomorphic, but contrastive, it is best left to teachers of each individual language. General grammatical nomenclature, on the other hand, can be dealt with more casually, for many principles cross language boundaries.

${ }^{13}$ Even though research has proven that ten to fifteen years ago - when all students of English studied Reed and Kellog diagrams $-\mathrm{L} 2$ instruction was not more effective, at least this problem of using precious L2 class time to explain basic concepts which lie behind L1 grammatical nomenclature and to illustrate fundamental uses of certain structures was not as frustrating as it is today.

7. Gaudiani, Clair. Teaching Writing in the Foreign Language Curricabum Washington: CAL, 1981.

8. The Losole Colleze Writing Hondboak. Ed. John R. Breihan \& Barbara C. Mallonee. Np, nd.

9. Omaggio; Alice C. Teaching Lorguage in Contad: Proficiency Oriented Instruction. Boston: Heinle, 1986.

10. Ringbom, Haan. The Role of the First Language in Forcign Langrage Leaning. Philadelphia: Multilingual Matters, 1987.

11. Scherer, George A. C. \& Michael Wertheimer. A Psycholinguistic Experiment in Fonagin Language Toaching. New York: McGraw-Hill, 1964.

12. Smith, P. D. A Comparison of the Cognitioe and Audiolingual Approades wo Foraign Larguage Instruction: The Pennolveria Project Philadelphia: CCD, 1970.

13. Yule, George. The Study of Lorguage. Cambridge: Cambridge Univ. Press, 1985.

14. Zorach, Cecile. English Grammar for Students of German. Ann Arbor. Olivia \& Hill, 1980. 